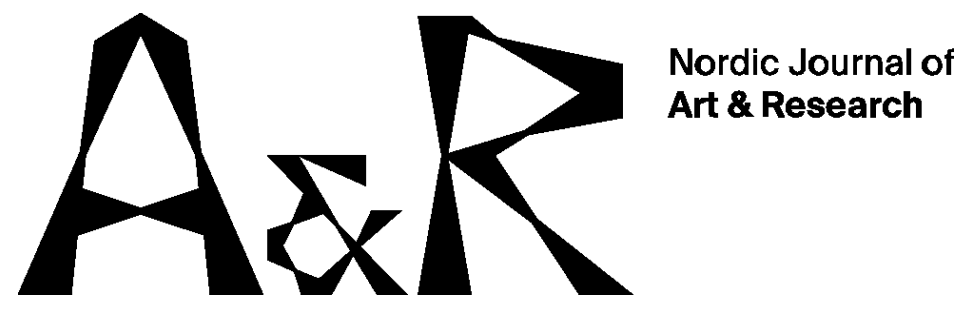

\title{
Teateranmeldelser som tekster i lærerutdanning - med utgangspunkt i Det Norske Teatrets Edda, 2017
}

\author{
Stig A. Eriksson ${ }^{1}$, Bjørg Oddrun Hallås², Eldar Heide ${ }^{3}$, Bente Opheim Brathetland ${ }^{4}$, \\ Per Bjørnar Grande 5 \& Mette Bøe Lyngstad ${ }^{6}$ \\ Høgskulen på Vestlandet
}

\begin{abstract}
Sammendrag: I artikkelen diskuteres åtte anmeldelser av Det Norske Teatrets produksjon Edda i 2017. Artikkelen er utviklet kollektivt, på grunnlag av en felles interesse for myter og fortellinger, forankret $\mathrm{i}$ forskergruppen «Mytologi, eventyr og forteljing i danning og didaktikk» ved Høgskulen på Vestlandet (HVL). Forfatterne av artikkelen er forskere og lærerutdannere på ulike fagfelt. Det konkrete utgangspunktet er Robert Wilsons Edda-oppsetning, og anmeldelsene av den. Vår intensjon er å bidra til styrking av lærerstudentens kunstog kulturkompetanse gjennom eksemplifisering av hvordan teateranmeldelser kan tas i bruk i

undervisningssammenheng. Gjennom en hermeneutisk og didaktisk tilnærming, i lys av forfatternes ulike faglige ståsteder, drøfter vi hvordan man kan bruke anmeldelser som fagtekster. Selv om artikkelen relaterer seg til en spesiell oppsetning, kan den likevel benyttes som en eksemplarisk modell for hvordan lærerutdannere kan anvende teateranmeldelser i ulike fag - og kanskje i neste omgang også inspirere til å oppleve teater.
\end{abstract}

Emneord: Teateranmeldelse, kunstmøte, norrøn mytologi, Edda, Robert Wilson, lærerutdanning.

\footnotetext{
${ }^{1}$ Professor emeritus i drama og anvendt teater ved Høgskulen på Vestlandet, Fakultet for lærarutdanning, kultur og idrett, Institutt for kunstfag. E-mail: stig.audun.eriksson@h.hl.no
${ }^{2}$ Dosent i kroppsøving ved Høgskulen på Vestlandet, Fakultet for lærarutdanning, kultur og idrett, Institutt for idrett, kosthald og naturfag. E-mail: bjorg.oddrun.hallas@hvl.no
${ }^{3}$ Førsteamanuensis i norsk ved Høgskulen på Vestlandet, Fakultet for lærarutdanning, kultur og idrett, Institutt for språk, litteratur, matematikk og tolking. E-mail: eldar.heide@hvl.no
${ }^{4}$ Førstelektor i historie ved Høgskulen på Vestlandet, Fakultet for lærarutdanning, kultur og idrett, Institutt for pedagogikk, religion og samfunnsfag. E-mail: bente.opheim.brathetland@hvl.no

${ }^{5}$ Dosent i KRLE ved Høgskulen på Vestlandet, Fakultet for lærarutdanning, kultur og idrett, Institutt for pedagogikk, religion og samfunnsfag. E-mail: per.bjornar.grande@hvl.no

${ }^{6}$ førstelektor i drama ved Høgskulen på Vestlandet, Fakultet for lærarutdanning, kultur og idrett, Institutt for kunstfag. E-mail: mette.boe.lyngstad@hvl.no 


\section{Norrøn mytologi som kunst og kulturuttrykk i skolen og i kulturlivet}

Mytiske fortellinger kan uttrykke ulike kulturers verdensbilde, hvordan man oppfatter at verden henger sammen, og menneskets plass i den (Kværne, 2016). I førkristen tid møtte folk myter fra de var barn, og disse mytene var nøkkelen til å forstå verden og samfunnet (Steinsland, 2005, s. 28-34). De skisserte hvordan det lokale landskapet, universet og kreftene i verden ble til, sa noe om samfunnsklassene, hva som var normalt og unormalt, hva som var god og dårlig moral og gav mening i tilværelsen.

Norrøn mytologi er sentral i nordisk kulturarv, gjennom at våre forfedre levde i den, og at den tilhører vårt hjørne av verden (Steinsland, 2005). Samtidig har den vakt stor interesse også utenfor Norden, delvis fordi vi ikke har så rike og autentiske kilder til noen annen førkristen mytologi - når vi ser bort fra gresk-romersk mytologi. Våre viktigste kilder til norrøn mytologi er rundt 15 gudedikt som regnes til diktsamlingen Den eldre Edda, nedskrevet på Island på 1200-tallet, og Snorre Sturlasons Den yngre Edda, som er hans sammenstilling og tolkning av de mytologiske tekstene som var tilgjengelige for ham på 1200-tallet.

I grunnopplæringen skal elever lære om norrøn mytologi i flere fag. I KRLE-faget er de innom temaet i forbindelse med kristningen. I samfunnsfag skal elevene lære om samfunnsutviklingen i vikingtiden, og den norrøne forestillingsverdenen er sentral for å forstå denne. I norskfaget $\mathrm{i}$ grunnskolen skal elevene samtale om personer og handling i eventyr og fortellinger, og $\mathrm{i}$ videregående skole skal de stifte bekjentskap til norrøne tekster og fortellemåter og verdier i blant annet myter (Utdanningsdirektoratet, 2013). Mange av de norrøne tekstene har en dramatisk og performativ grunnform (Gunnel, 1994, 2008) og drama kan være en aktuell arbeidsform i arbeid med slike tekster. Ettersom elevene møter den norrøne mytologien i ulike fag og på ulike tidspunkt gjennom et utdanningsløp, åpner det for å tenke varierte arbeidsmåter, tverrfaglig og kreativt både i skolen og ikke minst i lærerutdanningen.

Mytene inngår i et idéunivers som står fjernt fra våre dagers naturvitenskapelige verdensbilde, og de mytologiske tekstene kan også være vanskelig tilgjengelige rent språklig. I dagens samfunn vil mytologien lettere kunne vekke interesse for ulike aldersgrupper dersom mytene aktualiseres på ulike måter og gjennom flere medier. Det har særlig skjedd i barnehager og grunnskoler gjennom opplesing og dramatisering. For ungdommer er det særlig dataspill og filmer som gjenbruker mytologi. Et uvanlig interessant forsøk på aktualisering, av mytene, finner vi i Det norske Teatrets oppsetning $E d d a$, som hadde premiere i mars 2017. Utgangspunktet for oppsetningen var Den eldre Edda «i ein scenisk versjon ved Jon Fosse» (Fosse, 2017).

\section{Teateranmeldelse som fagtekst}

Vi har valgt å bruke $E d d a$-oppsetningen til å sette lys på en moderne kunstinstitusjons tolkning av dette gamle mytestoffet. Utgangspunktet er artikkelforfatternes besøk på Det Norske Teatret våren 2017, som ble innledet med et orienterende møte med sjefsdramaturgen på DNT, Carl Morten Amundsen, fulgt opp av en felles teateropplevelse av forestillingen Edda. Med denne referanserammen som bakteppe, undersøker artikkelen dagspressens anmeldelser av forestillingen. Vi spør oss hvordan disse anmeldelsene kan tolkes og brukes i lærerutdanning, som en type fagtekst som aktualiserer et kunstuttrykk i samtiden.

Anmeldelsene fungerer som primærdata, men våre egne opplevelser av teaterstykket, analyse av anmeldelsene og våre faglige ståsteder utgjør samtidig en form for sekundærdata som er med på å 
farge refleksjonene. Artikkelens hovedgrep er imidlertid at vi undersøker teateranmeldernes resepsjon av stykket ut fra interessen for hvilken mening det kan gi i dagens samfunn og hvilke reaksjoner det vekker. Det radikale grepet vårt er å betrakte anmeldelsene som fagtekst i en lærerutdanningskontekst. Anmeldelsene, som etter premieren ble trykt i dags- og ukepressen, er skrevet av åtte ulike anmeldere. Anmeldelsene har vi primært funnet i mediedatabasen Retriever (https://www.retriever.no), som dekker over 300 norske aviser og tidsskrifter. Anmeldelsene har stått i Morgenbladet (10.03.17), Aftenposten (06.03.17), Klassekampen (06.03.17), Vårt Land (06.03.17), Dagbladet (06.03.17), Verdens Gang (06.03.17), Dag og Tid (17.03.17) og Svenska Dagbladet (06.03).

I artikkelen gir vi våre oppfatninger av de åtte anmeldernes tekster, som er svært ulike, og viser relevansen tekstene kan ha for våre lærerutdanningsfag, som drama, samfunnsfag, norsk, KRLE og kroppsøving. Tekstene analyseres fra ulike fagbakgrunner i fem lærerutdanningsfag. Valget av akkurat disse fagene sammenfaller med forfatternes faglige ståsteder og er følgelig også begrunnelsen for utvalget.

\section{Teateranmeldelser som objekt for kunst- og kulturmøter i lærerutdanning}

Læreren er for mange barn en av de første kulturformidlere de møter, noe som stiller krav til læreren og lærerutdanningen. I vårt grissgrendte land er muligheten for å se profesjonelle teaterforestillinger begrenset. Ingenting kan erstatte selve teateropplevelsen, men det å studere en teateranmeldelse kan gi inspirasjon til å diskutere fortellinger som ligger til grunn for en teaterforestilling. Lærere er ansvarlige for planlegging, gjennomføring og vurdering av egen undervisningspraksis. Vi ønsker å vise hvordan det å betrakte teateranmeldelse som tekst i ulike fag kan gi lærere inspirasjon til å arbeide med kunstog kulturuttrykk i undervisningen. Som lærerutdannere må vi gi våre studenter erfaringer med å utforske tekstene, enten som et supplement til selve mytene eller kun som inspirasjon til skapende og kreative prosesser innenfor andre tema.

Kunstmøter er aktiviteter som skjer mellom kunsten og deltakerne som på ulike måter forsøker å tolke kunstobjektet - i seg selv eller også i dets møte med publikum. Dette gir rom for fortolkningskunst. «Et kunstobjekt kan være litteratur, billedkunst, dans, drama, teater, film og musikk i tillegg til kunstnerisk arbeid utført ved kombinasjonen av to eller flere av de nevnte ytringsformer, for eksempel i installasjoner og performances» (Østby, 2007, s. 54). Det er mye som kan fungere som kunstmøter. Guri Lorentzen Østbye (2007) ser på kunstmøter som hendelser, der man integreres med kunsten i vid forstand. Hun definerer kunst som kunstobjektet, og er opptatt av dialogen som oppstår mellom kunsten og deltakeren. Østbye (2007) skriver at fellestrekket ved kunstformene er at de først og fremst er poetiske og estetiske erkjennelsesformer, med mulighet for innflytelse også i diskursens verden.

Avisanmeldelsene er opplevelsesrelaterte kunnskapskilder og uttrykk for hvordan kunnskap kommuniseres og utvikles. Tekstene uttrykker noe som anmelderen vil ha fram, og dette tolkes av leserne. En anmeldelse av en teaterforestilling vil tolkes forskjellig avhengig av om leseren har sett teaterstykket som omtales eller ikke. Lesing av anmeldelser, som alle typer tekster, gir en forståelse for tekstmangfold, hva kunnskap er og hvordan mening dannes.

Teateranmeldelsene fra $E d d a$-forestillingen forteller om en nyskapende og eksperimenterende teateroppsetning. Anmeldelsene løfter fram ulike perspektiver på moderne teater. Om vi går anmeldelsene nærmere etter i sømmene, vil de kunne bidra til større nysgjerrighet for hva teater er og kan være. Slik kan anmeldelsene i seg selv bli et første kunstmøte. For hva er teater for de fleste, 
hvilke teatertradisjoner er mest framtredende og med hvilke briller «skrives» en anmeldelse og hvilke briller «leser» man teateranmeldelsene?

Vi ønsker å vise at teateranmeldelser kan fungere som et objekt for en type kunstmøte, som kan studeres, tolkes og anvendes i mange fag i lærerutdanningene. I mange av landets grunnskolelærerutdanninger får studentene erfaring med drama. ${ }^{7}$ Flere anmeldere trekker fram komponenter som berører drama- og teaterfagets grunnelementer, virkemidler og valg. Men som vi viser i det følgende, kan anmeldelsene også brukes i fagene KRLE, kroppsøving, norsk og samfunnsfag. Gjennom å nærlese anmeldelsene, med noen skole- og lærerutdanningsfag sine perspektiver, har vi funnet mønstre som åpner for både detaljer og helheter.

\section{Hermeneutisk nærlesing og eksemplarisk didaktisk anvendelse}

Anmeldelser er korte fagtekster skrevet av journalister, forfattere eller andre med fagbakgrunn på temaet de behandler. De velger vinkling ut fra egen bakgrunn, ønske fra redaksjonen eller med utgangspunkt i avismediet. Anmelderen utformer tekstens språk, innhold og fortolkning, og iscenesetter slik også seg selv. Christensen (2012) har diskutert formen og språket i slike korte anmeldelser. Hun spør bl.a. hvordan anmelderes retorikk utvikler seg i vår tid og påpeker at skribentens selviscenesettelse både vil kunne åpne opp og tilsløre. Birkeland \& Tønnesen (2016) minner om, når det gjelder fagtekster generelt, at også mediet (her: dagspressen) som teksten produseres og formidles $i$, vil virke inn på formen og hvordan man som leser handler med teksten. Dette er elementer som inngår i et hermeneutisk fortolkningsperspektiv, dvs. det som handler om «sentrale spørsmål om betydning, mening og forståelse» (Lægreid \& Skorgen, 2001, s.7). I vår kontekst dreier dette seg om tekster som er skrevet ut fra en estetisk erfaringsverden som anmelderne skriver ut fra (og som vi i dette tilfellet også selv har en opplevelse av), men også om anmeldernes (og våre egne) kunnskaper - om teater, om Wilson og Fosse, om norrøn mytologi, om $E d d a$, samt det assosiasjonsrommet til gammel og ny tid som forestillingen skaper. Hele dette komplekset krever hermeneutiske grep som fortolkning av meningsmuligheter og pedagogisk anvendelse av dem.

Hermeneutisk, kvalitativ nærlesning er valgt fordi vi har ønsket å nærme oss tematikkene i oppsetningen gjennom forstehåndsforståelse av anmeldertekstene (Thagaard, 1998), og samtidig med de blikkene som en flerfaglig tilnærming muliggiør, i motsetning til en konsentrasjon om ett eller to regifag. En slik hermeneutisk tilnærming, med individuelle og kollektive nærlesinger (Smith, 2016), representerer også en innholdsanalytisk tilnærming i tråd med Hsieh og Shannons kvalitative innholdsanalyse (2005). I analysearbeidet har vi først foretatt en summativ tilnærming og lett etter ord og formuleringer i hver anmeldelse for å finne et mønster. Alle forskerne gjorde en individuell lesing av de åtte anmeldelsene hvor vi noterte ord og tema fra anmeldelsene som vi fant interessante. Som Fauskanger \& Mosvold (2014) anbefaler, har vi også gått videre med materialet og deretter prøvd det ut med en mer konvensjonell tilnærming, hvor vi i fellesskap har utforsket materialet for om mulig å kunne si noe om hva tekstene kunne formidle av tema, diskurser og tankegods. Her har vi også lett etter eventuelle nye kategorier vi først ikke var oppmerksomme på. Noen slike fellestema var for eksempel: Den historiske Edda-diktningen, Robert Wilson sin iscenesettelse av Jon Fosses

\footnotetext{
${ }^{7}$ En kartlegging fra høsten 2017 viser at rundt $60 \%$ av lærerutdanningene tilbyr 0-15 timer obligatorisk dramaundervisning, mens de som har mest tilbyr 70-90 timer for lærerstudentene i løpet av utdanningen (Dramaundervisning i grunnskolelærerutdanningene. Nasjonal kartlegging og eksempler på best practice. Rapport, 2017: https://dramaogteater.no/ny-rapport/). Regjeringen har meldt at den vil styrke de praktiske og estetiske fagene i grunnskolen (Meld. St. 28. (2015-2016).
} 
gjendiktning, rolletolkning, bevegelsesrepertoar og kostymer, og anmeldernes egen iscenesettelse av eget faglige ståsted. Vi valgte deretter å ta utgangspunkt i ulike lærerutdanningsfag for videre analyser. Fagene vi representerer er således blitt styrende for hvordan vi til slutt har tolket tekstene - de er våre analysekategorier - og for hvordan vi presenterer våre endelige analyser i artikkelen.

Våre analyser er eksemplifiseringer av hvordan teateranmeldelsene kan leses og tolkes. Her prøver vi å gi et bidrag til det didaktiske feltet basert på den urgamle pedagogiske og poetiske tradisjonen som eksempelet representerer. Exemplum (lat.) eller parádeigma (gr) handler om 'forbilde', om 'mønster'. Eksempel er noe som fører inn i et stoff gjennom paralleller, metaforer eller assosiasjoner. Eksempelet «fremmer leseevne og kritisk sans»; eller sagt på en annen måte: «Eksempelet prøver å få oss til å sjå» (Nyrnes, 2002, s. 208, s. 258).

Eksempeltilnærmingen vår er flersidig, men samtidig også avgrenset. I det følgende åpnes først det didaktiske rommet gjennom ett grundig nærlesingseksempel fra ett faglig perspektiv: teaterhistorie, som her er mest naturlig, gitt at teaterforestillingen og kritikerresponsene på den er artikkelens utgangspunkt og ramme. Deretter formidles et mer flerstemmig perspektiv, som impulser til hvordan stoffet kan anvendes i andre fag.

\section{Presentasjon av teateranmeldelsene i lys av ulike fagtradisjoner}

Her presenteres og drøftes anmeldelsenes potensial som fagtekster og hvordan de kan skape kunstmøte $i$ en integrert lærerutdanning. Eksemplene representerer et tolkningsmangfold med kritiske refleksjoner, og hentes fra fagene drama, KRLE, kroppsøving, norsk og samfunnsfag.

\section{Teateranmeldelsene av EDDA-produksjonen i et teaterhistorisk lys}

Som første eksempel har vi valgt et teaterhistorisk perspektiv. Selv om drama/teater for tiden bare er et såkalt skolerelevant ${ }^{8}$ fagstudium i lærerutdanning, utgjør det for denne artikkelen et særlig relevant kontekstuelt fokus. Eksempelet viser hvordan man kan analysere anmeldertekstene ut fra ett faglig perspektiv og én relatert faglig terminologi.

$E d d a$-forestillingen er først og fremst blitt den nordamerikanske stjerneinstruktøren Robert Wilsons impresjonistiske tolkning av mytologien, og hvor bare en del av Fosses tekster er tatt med (Det Norske Teatret, 2017). Det kan man være kritisk til. Men nettopp spennet mellom mytologien slik den var og det Edda-bildet forestillingen gir, gjør den interessant. Wilsons bruk av musikalske og visuelle referanser til aktuell popkultur og dagens økologiske utfordringer er med på å skape interesse og reaksjoner hos både anmeldere og publikum.

Med dette in mente, vil vi i det følgende synliggjøre noen linjer fra teaterhistorien som kan ha bidratt til å perspektivere og fargelegge Wilsons konsepsjon av Edda som teaterhendelse. Etter en gjennomgang av de åtte anmeldelsene åpner det seg flere teaterhistoriske perspektiver - parallelt med de samtidskunstreferanser som man naturlig forventer når en produksjon av tidens ledende internasjonale iscenesetter blir anmeldt. Et tydelig hovedperspektiv i så måte - skjønt ingen av anmelderne anvender det som begrep - er reteatralisering. Begrepet forbindes gjerne med

\footnotetext{
${ }^{8}$ Drama har vært et studiefag i norsk lærerutdanning på minst 60 stp-nivå helt fra 1971. Men etter at drama som fordypning i allmennlærerutdanningen ble begrenset til 30 stp. etter Grunnskolelærerreformen (GLU) av 2009, har tilstrømmingen til dette tilbudet minket. Ønsker man større fordypning i faget, kan man gå veien om bachelor eller master i drama/teaterfag.
} 
reteatraliseringsbevegelsen som betegner ulike former for brudd med naturalismen etter 1890, som symbolismen og surrealismen, men som også omfatter de russiske formalistene og andre modernismeeksperimenter i perioden mellom de to verdenskrigene (f.eks. Sjklovskij, Eisenstein, Piscator og Brecht). Reteatralisering innebærer å fjerne seg fra naturalismens illusjons- og innlevelsesidealer gjennom å ta aktivt i bruk teatrets grunnleggende kunstelementer - som fysisk uttrykk, stemme og bevegelse, og visuelle og auditive framstillingsformer som lys, scenografi, og kontentum. Teateret skulle befris fra kravet om virkelighetsillusjon og heller påvirke publikums sanser og følelser gjennom underliggjøringsgrep i kunsten. Teaterkunstnerne ønsket å framheve og utøve teatrets egenart som kunst, og gjerne uavhengig av ordet og litteraturen; man søkte etter å teatralisere teateret: «Teatern skulle manifestera sig med hjälp av sina egne medel, sin egen tjuskraft, inte endast vara en trogen verklighetskopia» (Avén, 1962, s. 280).

Reteatraliseringen kan betraktes som starten på en kunstteaterbevegelse som Robert Wilson er en av dagens ledende eksponenter for - innenfor den såkalte postdramatiske tradisjonen (Lehmann, 2006) - men som altså har en mer enn 125-årig utviklingshistorie å trekke på. I tillegg kan det identifiseres enda eldre impulser til Wilsons teatrale formspråk, som også flere av anmelderne nevner. Tydeligst av disse er idéen om multikunstverk, med tilnærmet likeverdighet mellom visuelle, auditive og tekstlige virkemidler, noe som i stor grad minner om Richard Wagners Gesamtkunstwerk. Wagners teatervisjon om helhetskunstverket - «ett samspel mellom opera, drama og ballett» (Lehmann, 2006) - stammer fra 1850. Aftenpostens Mona Levin bruker nettopp det wagnerske begrepet til å kommentere det hun opplever som grunntonen i $E d d a$-forestillingen: «Wagner, for øvrig sterkt inspirert av det norrøne, vaker under og over med sitt Gesamtkunstwerk, noe den amerikanske teaterlegenden Robert Wilson utvikler og tar videre med vår tids teaterteknikk». En lignende observasjon gjøres av Kjersti Juul i Vårt Land: «Wilsons inngang til teatret går via arkitekturen, billedkunsten, dansen og musikken. I en slags postmoderne «wagnerisme» presenteres $E d d a$ som multimedial kunstform». Videre observerer mange av anmelderne Wilsons skaping av tablåer som et gjennomgående regigrep. Anette Therese Pettersen, Morgenbladet, sier: «Vi presenteres for tablåer, bevegelige bilder, der én og én gudehistorie eller gudeskjebne presenteres»; Levin iakttar «hvert scenebilde som et fantastisk maleri»; Juul opplever at «Edda presenteres som estetiske perler på en snor, gjennom stiliserte tablå, i en slags stilren karnevalisme», mens Dagbladets Lillian Bikset registrerer at teksten ikke alltid framsies, men at «den framgår visuelt, i bevegelige tablåer» - i likhet med Svenska Dagbladets Lars Ring, som karakteriserer det som «djärva, högoktaniga bildspel».

Det er vanskelig ikke å assosiere slike observasjoner til det religiøse middelalderteatrets formspråk, som nettopp la vekt på å fange ladede og spenningsfylte øyeblikk i tablåer, snarere enn i tekst - av hensyn til et publikum som selv verken hadde teksten eller forstod språket, da forkynnelsen gjerne foregikk på Latin. Den teatrale tablåkunsten hadde i middelalderen en tosidig oppgave:

Att ge synligt uttryck åt det kristna trosinnehållet och den kristna världsbilden med hjälp av symboler och stiliserade "situasjoner" och att i bild berätta för den icke läskunniga menigheten vad den genom uppläsningen av de bibliska texterna uppfattade med hörseln men av olika skäl inte alltid hade så lätt att förstå (Avén, 1962, s. 47).

Med dette perspektivet for øyet, får tablåbruken i $E d d a$-produksjonen en ekstra dimensjon, nemlig at den bruker et teatralt formspråk som har likhetstrekk med tablåbruken i middelalderens kirkespill. Det karnevalistiske performative uttrykket, som Levin observerer, tilhører også middelalderteatrets historie, dvs. dets folkelige utløp.

Reteatraliseringens teori og praksis skyldes i stor grad impulsene som kom fra den sveitsiske scenografen Adolphe Appia, gjennom verket Die Musik und die Inszenierung, 1899, og den engelske 
scenografen Edward Gordon Craigs håndbok On the Art of the Theatre, [1905] 1911. Det overbyggende idealet hos begge disse teaterarkitektene (eller teatermalerne, som de også ble kalt) er å bryte med realismen og naturalismens scenografiideal og la scenebildet få et abstrakt, stilisert og symbolsk uttrykk som appellerer til fantasi og bildeskaping, som på den måten kan engasjere og vitalisere publikums opplevelse av teaterhendelsen, dvs. at «utstyrsel och dekoration på scenen inte skall försöka återge en exakt bild av den verklighet pjäsen handlar om utan försöka bygga upp en förnimmelse av denna verklighet i åskådarnas fantasi» (Avén, 1962, s. 281). Lyset var for Appia et sentralt uttrykksmiddel (op.cit., s. 282) som skulle brukes til å skulpturere og skape kontraster. «För Appia var en teaterföreställning en självständig skapelse i rummet, en rörelse av kroppar och ljus i dramatisk rytm» (ibid.).

Hos Craig skulle selve scenerommet være forestillingens estetiske imperativ, som måtte proporsjoneres arkitektonisk og skulpturelt uten forsøk på perspektiveffekt eller lignende dekorasjonsvirkning. Craig betonet sterkere enn noen andre før ham at teatrets egenart og selvstendighet ligger i det visuelle og fysiske uttrykket, som også er dets kunstneriske opprinnelse. Han bestemte «rörelsen, dansen och handlingen - icke ordet - som dess ursprung» (ibid.). Det er ikke vanskelig å se at dette kan ha vært provoserende nytt i tiden. I vår tid - mer enn 100 år senere - kan det se ut til at teateranmelderen er blitt mer fortrolig med det visuelle som språk: «En ting er det ikke tvil om: Robert Wilsons to timer lange sceniske fortolkning av vår norrøne gudeverden er en enestående visuell opplevelse», bekjenner Ida Lou Larsen i Klassekampen. Selv om hun erkjenner at det kanskje kreves spesielle evner til å knytte Wilsons sceniske elementer til vår moderne tid, gir likevel $E d d a$ «en uvanlig fascinerende opplevelse som utvider vår oppfatning av hva teater kan være». For Pettersen i Morgenbladet er Edda «en spesielt assosiativ forestilling, som et tanker om som utfolder seg inni hodet mitt mens jeg betrakter det som skjer i scenerommet». Pettersen observerer at Wilsons formspråk inngår i et repertoar med gjenkjennelige elementer: «Edda består av variasjoner over Wilsons tablårepertoar - så som langbord-oppsett og bruken av hele scenerommet (høyde og dybde)». Borghild Maaland Eberson i $V G$ betrakter konsepsjonen som et sanseunivers: «Wilson bruker teksten som verktøy til å skape et kreativt alternativ med tablåer av skulpturell og nøye koreografert karakter, der bruken av lys, masker og musikk er ment for tilskuernes sanser». Samtidig som disse anmelderne eksemplifiserer en viss fortrolighet med det «teatralske» (Larsen, Klassekampen) som samtidsteaterform, er nok fortsatt en teaterforestilling som Edda vanskelig tilgjengelig, kanskje også skuffende, om det primært er ordet, selve Edda-diktingens poesi og innhold, man vil oppleve. Dette fornemmes bl.a. hos Bent Kvalvik i Dag og Tid: «Robert Wilsons Edda er festleg å sjå og høyre til, men bringar ikkje mytane nærare». Han savner fortellingene på scenen, formidlingen av $E d d a$-stoffet i en gjenkjennelig form, som nok hos Kvalvik implisitt er ordteatrets form: «Det vert eit problem i ei framsyning som denne, som er visuelt blendande og musikalsk raffinert, men som avstår frå å vere instruktivt forteljande». For Kvalvik er forestillingen «for abstrakt».

På samme måte som med reteatraliseringsbegrepet, er ikke arven fra Appia og Craig spesifikt nevnt i noen av anmeldelsene, hverken som impuls eller som tradisjon. Men med den teaterhistoriske lesningen av anmeldelsene som her er anlagt, er parallellene fra det moderne visuelle teatrets gjennombrudd rundt 1900 til den wilsonske postdramatiske teaterestetikken ganske åpenbare (jfr Lehmann, 2006, s. 49, s. 89). Dette gjelder ikke minst diskusjonen om skuespilleren som marionett, som stammer fra Craig og som direkte og indirekte berøres i flere av anmeldelsene. Det refereres f.eks. til «skuespillernes konstruerte bevegelser» og «marionettegrep» (Juul, Vårt Land), «actiondukke» (Bikset, Dagbladet), «Caprino-dukkeaktig» og «animert oppførsel og utseende» (Pettersen, 
Morgenbladet), og «dokketeater med levande dokker» (Kvalvik, Dag og Tid). Craigs teatervisjon gikk ut på å erstatte skuespilleren, som han betraktet som en «fundamentalt naturalistisk företeelse» (Avén, 1962, s. 283), med en «Über-Marionette». Denne kunne avløse skuespillerens påtrengende fysiske realitet og oppfattes som et idealisert vesen, «full av eld och demoni och utan egoism» (Craig sitert i Alvén, ibid.). Dette ligger ganske tett på Levins beskrivelse av skuespillerne i $E d d a$ som konturer av de norrøne gudene: «Alle er tannhjul i Wilsons større enhet, men hver og en utfyller sin rolle med spesifikk dirigert karakter» (Levin, Aftenposten). Her ligger det også et visst slektskap til en annen teaterhistorisk referanse som kommer igjen hos flere av anmelderne, nemlig den stiliserte og forstørrede spillestilens likhet med de to klassiske japanske sjangrene: Noh-teater og Kabuki - begge ulike sjangre som forener skuespill, dans og musikk (Gesamtkunstwerkstanken), som etterstreber stemning og atmosfære gjennom stilisering, masker (Noh) eller sminkemasker (Kabuki), og som forsøker å realisere en slags overvirkelig framstilling av karakterenes vesen gjennom ikke-spill, i realistisk forstand (Brauneck \& Schneilin, 1986, s. 461, s. 642).

To impulser til fra reteatraliseringens historie fornemmes i anmeldelsene; den ene fra Bertolt Brechts episke teater, den andre fra Antonin Artauds grusomhetens teater. Men heller ikke her er disse dramatikernes navn trukket fram spesifikt i noen av anmeldelsene. Imidlertid, når Pettersen (Morgenbladet) presenterer Edda som «en ikke kronologisk fortelling» og Larsen (Klassekampen) refererer til «de ulike episodene», mens Bikset (Dagbladet) ser fortellingen bestående av «flyt» og av «brudd», er alle disse betraktningsmåtene karakteristika for Brechts episke teaterform. Riktignok er $E d d a$-diktningen i seg selv episk i sine grunnformer, så derfor er de episke fortellergrepene i denne oppsetningen kanskje ikke overraskende. Men de framstår i vår lesning som brechtske. I de episodiske situasjonene, og i bruddene, oppnås det Brecht omtalte som underliggjøring (Verfremdung): «Det å underliggjøre en hendelse eller en karakter betyr ganske enkelt å ta det selvfølgelige, kjente, innlysende ved hendelsen eller karakteren og framkalle forbauselse og nysgjerrighet over den» (Brecht, 1963, s. 101. Vår oversettelse). Leser man alle anmeldelsene i sammenheng er, ikke minst, dette prinsippet oppnådd i Edda-produksjonen. Dessuten står Brecht utvilsomt på Wilsons inspirasjonsliste. Blant hans berømte oppsetninger er bl.a. en versjon av Brecht/Weills Tolvskillingsoperaen på Berliner Ensemble i 2007, som gjestet festspillene i Bergen i 2009. Impulser fra/til Artaud ligger i forestillingens «magiske» univers (Larsen, Klassekampen; Juul, Morgenbladet). Artaud kan betraktes som en surrealistisk opprører som er sterkt kritisk til Vestens rasjonelle forståelsesmåter og fragmentariske kulturforståelse. Han er også en tidlig forkjemper for å gi forrang til fysiske og visuelle teateruttrykk; han er «teatermannen som vil redusere tekstens plass i teatret og skape et fysisk teateruttrykk med utgangspunkt i det sceniske rom» (Helgheim, 2000, s. 152). Hos Artaud er framfor alt drømmen modellen for en ikke-hierarkisk teaterestetikk (Lehmann, 2006, s. 84), dvs. hvor ingen av uttrykkselementene skal kunne dominere. Dette ser vi også hos Wilson, som klart er påvirket av Artaud (Bennett, 2009, s. 12). I teateranmeldelsene fra Edda kommer drømmeassosiasjoner til uttrykk hos Pettersen (Morgenbladet), som karakteriserer Edda «som en spesielt assosiativ forestilling», og kopler sine inntrykk til Strindbergs Ett Drömspel - en av symbolismens kjente forestillinger - men også hos Larsen (Klassekampen), som refererer til «den drømmeaktige formen» i forestillingen. Juul (Vårt Land) kontrasterer det magiske i mytologien med det rasjonelle i vår egen virkelighetsoppfattelse: «Det publikum får presentert på scenen, skaper stadig rom for tankesprang og digresjoner bort fra mytologiens verden og fortellingens opprinnelse. Samtidig sidestilles det magiske med det rasjonelle på den selvfølgeligste måte. Vi tvinges til å justere vår virkelighetsoppfatning». Symbolisme- og drømmetemaet kan vel også framtolkes i Ebersons $(V G)$ kommentar: «Referansene til ymse tiders populærkultur er synlig, iblant befinner vi oss i western-land, 
iblant i stumfilmens verden, og andre ganger i svært karikerte tegneserieland, før vi ender i en symboltung, men samlet og vakker slutt».

Nærlesning av disse anmeldertekstene i et teaterhistorisk perspektiv gir et historisk assosiasjonsrom og åpner samtidig opp for refleksjoner rundt samtidsteaterets form og innhold.

\section{Religionens rolle i anmeldelsene av Wilsons Edda}

$E d d a$-tekstene er den viktigste kilden vi har til kunnskap om den hedenske religionen, men hva kan vi lære om religion av å lese disse anmeldelsene? Anmelderne er opptatt av at forestillingen fokuserer på bruddet, slutten på den gamle troen og den nye som er i emning: Ring i Svenska Dagbladet er den anmelderen som tydeligst poengterer dette. Ring ser slutten i lys av en ny æra der lyden av kirkeklokkene innvarsler en ny tids fødsel. Dette underbygges både av kristeninspirerte sceneeffekter og Arvo Pärts sakrale musikk. Juul i Vårt Land fokuserer på at man i teateroppsetningen forlater den gamle gudeverden til fordel for et eksistensielt møte med oss selv. Gudsdyrkelsen henvises til den moderne dyrkingen av kjendiser. Moderne religion oppstår gjerne ved at mennesker blir guder i hverandres øyne. Eberson i $V G$ er inne på det samme når hun kritiserer oppsetningen for å koble norrøn religion og glamrock; det «skaper [...] sprik i sammenhengen».

I anmeldelsene er det en klar kritikk av spriket mellom teateroppsetningen og oppsetningens opprinnelige tekstgrunnlag. Ingen av anmelderne synes at forestillingen gir en god innføring i norrøn mytologi. Det er imidlertid en interessant spenning mellom de anmelderne som framhever Wilsons visuelle geni og de som legger vekt på hans mer subjektive lesning av grunnteksten.

Et par av anmelderne legger vekt på at Wilson har skapt en form for syntese mellom kristendommen og den norrøne mytologien. Det er derfor kuriøst at ingen har poengtert den store forskjellen mellom de to religionene, hvor den ene er voldslegitimerende og den andre har pasifistiske ideal. Kvalvik i Dag og Tid er inne på denne problematikken når han tar opp stykkets etikk. Kvalvik påpeker en mangelfull kontrast mellom godt og ondt, en mangel som går tilbake til de opprinnelige $E d d a$-tekstene. Deres etikk handler jo ikke om godt/ondt, men om orden/kaos og gjensidig avhengighet.

Levin i Aftenposten er den som går mest religionsvitenskapelig til verks i sin anmeldelse. Hun ser samsvar mellom den norrøne opprinnelsesmyten, med dens utvikling mot undergang, og en typisk gnostisk skapelsesmyte, der skapelsen foregår gjennom eoner (ulike tidsaldre). Dette er en dristig sammenligning, men den gnostiske skapelsesmyten hvor det materielle ligger i det uforløste, har helt klart en klangbunn i den skjøre skapelsen og den norrøne religionens ugjenkallelige bevegelse mot et ragnarok. Det må allikevel påpekes at i vikingenes verden er det ingen personlig frelse, ei eller noen forløsning gjennom befrielse fra materien.

Anmelderne mener at gudene er, mer eller mindre, blitt mennesker, ikke bare menneskelige. Pettersen i Morgenbladet tolker gudenes verden i stykket som menneskets tragiske verden. Teologi er blitt til antropologi og «det er synd på menneskene». Kvalvik i Dag og Tid påpeker stykkets statusmangel: Gudenes hierarki er nivellert. Skikkelsene er mer å betrakte som mennesker enn guder. Hun hevder derfor at stykket ikke er en innføring i gudelæren, men heller et eksistensielt møte og en opplevelse av et kaos i forfall. De gamle norrøne mytene ivaretar, ifølge Kvalvik, en forståelse av at tilværelsen er skjør.

Ifølge Larsen i Klassekampen greier ikke Wilson å forene de gamle mytene med dagens populære myter. Hun ser stykket som en form for degradering av den gamle mytologien. Skikkelsene er verken 
guder eller mennesker, men karikaturer. Dette tapet av historisk realitet synes ikke å bekymre de fleste anmelderne, men det gjør stykket vanskeligere å anvende i undervisningssammenheng. Om det er vår verden eller vikingenes verden som bryter sammen, er ikke godt å si, skriver Pettersen, men teaterstykket er en tidløs fortelling om en verden som går under.

Sett i en samtidskontekst, framhever anmeldelsene at forestillingen er spennende og eksistensiell. Det som gjør stykket så utfordrende er det pessimistiske ved et univers som gudene holder på å miste kontrollen over. Ragnarok korresponderer klart med en samtid truet av klimatrusselen. På denne måten vil Wilsons $E d d a$ kunne fungere som et talerør inn i vår postmoderne verden. Dette er anmelderne enige om. Et spørsmål er likevel om stykket eksistensielt og kunstnerisk kan konkurrere med andre av vår tids apokalyptiske kommentarer til klodens skakkjørte tilstand.

Å bruke anmeldelsene fra forestillingen som grunnlag for å sammenligne den norrøne religionen og andre religioner, gir spennende diskusjonsmuligheter sammen med lærerstudenter. Hva sier anmeldelsene om norrøn religion og om hva stykket sier om den? Hva var det mest aktuelle i stykket? - og i den faktiske norrøne religionen? Den økologiske tolkningen av stykket - hvilket grunnlag har den i den faktiske norrøne religionen? Finnes det grunnlag for liknende vinklinger i andre religioner?

\section{Teateranmeldelser til bruk i kroppsøvingsfaget}

Selv om Norrøn mytologi ikke har en fagplanfestet plass i kroppsøvingsfaget, er det fullt mulig å benytte svært ulike kulturuttrykk i undervisning sammen med lærerstudenter. I arbeid med didaktikk kan ideer og inspirasjon hentes fra ulike arenaer, ulike fagfelt og ulike kunst- og kulturuttrykk. Kroppsøvingsfaget handler blant annet om bevegelse og kroppslig læring, samt deltakelse og samspill i bevegelsesaktiviteter (Utdanningsdirektoratet, 2015). Lek, tidsaktuelle og tradisjonelle bevegelsesformer i barnekulturen, og dans, står da sentralt. Opplæringen for studenter skal skje gjennom en praktisk orientert fagdidaktisk tilnærming. I en integrert lærerutdanning er det sentralt at studenter får ta del i en utforskende undervisning med varierte undervisningsformer. Eddaforestillingens teateranmeldelser kan benyttes til å tolke fram kroppsøvingsfaglige perspektiver: bevegelsesuttrykk, koreografi, skapende lek og kreativitet etc. Det å utforske, leke og utrykke seg med ulike bevegelser kan godt ta utgangspunkt i historier, eventyr, sagn og myter. Teateranmeldelsene blir da et læremiddel og en teaser for å få i gang diskusjoner og studentaktivitet om undervisning i faget.

I analysene av anmeldelsene, sett ut fra kroppsøving som lærerutdanningsfag, har anmeldernes beskrivelser av de kroppslige uttrykkene i teaterforestillingen vært interessante å studere. Anmelderne beskriver skuespillernes prestasjoner, den eldre Edda og Wilson sin stil, som svært kroppslig. Ved å identifisere ord, begreper og meningsinnhold fra anmeldelsene, er det ikke vanskelig å se hvordan lærere i kroppsøving kan bruke innholdet i tekstene til inspirasjon for arbeid med ulike tema i faget, og slik synliggjøre kroppsøvingsfagets egenart, læring med og gjennom kroppen.

Kroppsøvingslærerstudenter må få prøve ut varierende didaktikk hvor kreativitet, estetiske uttrykksformer og kunstuttrykk er inspirasjonskilde. I det følgende gis noen eksempler fra anmeldelsene. Når Juul i Vårt Land skriver: «Wilsons inngang til teatret går via arkitekturen, billedkunsten, dansen og musikken», er det i seg selv en inspirasjon til å tenke paralleller til dans som uttrykk i kroppsøvingsfaget. Det å vektlegge dans som en estetisk aktivitet er ikke en selvfølge i kroppsøving. Lindqvist m.fl. (2010) påpeker at idrettsemner og estetiske emner ofte har stått $\mathrm{i}$ motsetning i kroppsøvingsfagets praksiser i skolen. Undervisningen i faget vekter som regel de fysiske egenskaper framfor de estetiske. Dans er et flertydig kulturuttrykk, med ulike danseformer og stilarter (Clarke \& Crisp, 1981). Dansens estetiske og erkjennende aspekter i kroppsøvingsfaget har ofte vært 
vanskelige å få øye på i undervisningspraksiser, sier Eliassen (2006). Nordaker (2010) hevder også at dans ofte blir presentert som et fysiologisk, instrumentelt læringsprosjekt hvor dansens egenverdi kommer i bakgrunnen.

I Aftenposten beskriver Levin Edda-oppsettingen ved å bruke svært mange handlingsverb, altså beskrivelser av bevegelser og handlinger som skuespillerne utfører. Disse ordene, verbene, kan fremstå som en hjelp og støtte for å sette i gang kroppsøvingsaktivitet. Larsen i Klassekampen skriver at skuespillerne «henger, labber, fisker og glir». Dette er handlingsverb som kan inspirere, ikke til idretter, men til mer skapende bevegelsesaktiviteter. I Dagbladets anmeldelse beskrives teaterforestillingen med at rolletolkningene setter krav til «fysisk presisjon» og at bevegelsesrepertoaret er «detaljerte» og/eller «langsomme». Slike beskrivelser handler om analyse av bevegelser i tid, og rom, og er noe studenter kan arbeide med i sin utdanning. I $V G$ blir skuespillerne karakterisert som «sirkusartister», en god inspirasjonskilde for en lærerstudent som skal planlegge en kroppsøvingstime. Tar vi ut bruddstykker fra anmeldelsen i Vårt Land, kunne vi la assosiasjonene gå til sportsarrangement i like stor grad som til en teaterforestilling. Beskrivelser av teaterforestillingen med begreper som: «eksperimentell, dans, eksistensiell, dreining på hodet, spark i lufta, armer legges om, bevegelse, kroppslig, vulgær, bevege seg ...», er her tatt ut av konteksten, men viser likevel hvordan en teateranmeldelse kan inspirere til en samtale om ulike kroppslige uttrykk, ulike kunstmøter og ulike fags egenart.

\section{Teateranmeldelser som fagtekst i norskfaget}

Noe av det viktigste en norsklærerstudent skal utvikle er et skarpt tekstanalytisk blikk, siden en av de viktigste delene av norsklærerjobben er å gi tilbakemelding på tekster elevene skriver (Utdanningsdirektoratet, 2013). De teateranmeldelsene vi ser på er nyttige å øve analyseblikket på helst for dem som utdanner seg til ungdomsskole og videregående skole - fordi de alle er forsøk på å løse en oppgave som til dels er uløselig. En anmeldelse forventes å si noe om hva stykket (eller boka, filmen, e.a.) uttrykker, hva som er budskapet, eller i alle fall hva slags tematikk det tar opp. Her har vi imidlertid anmeldelser som må forholde seg til et utpreget postdramatisk, multimedialt, visuelt uttrykk, hvor det opprinnelige tekstgrunnlaget $E d d a$ bare er en liten del av forestillingens (utvidede) «tekst», og hvor uttrykket ikke nødvendigvis har et klart budskap. Utgangspunktet er Fosses «sceniske versjon» (Fosse, 2017). Men ifølge anmeldelsene, og de supplerende artiklene til oppsetningen på DNTs hjemmeside (Det Norske Teatret, 2017), spilte Fosses tekst en helt underordnet rolle i oppbygningen av forestillingen. Den ble dominert av de visuelle og musikalske elementene utformet av Wilson. Replikkene i det ferdige stykket er for det meste hentet fra Fosse, men utvalget (det meste av Fosses tekst er utelatt) og kombinasjonene er et konglomerat av mange medarbeideres bidrag. Da skapes det samtidig et vidt tolkingsrom av forestillingsteksten, som er et konsept, og bærer Wilsons navn.

Hvordan anmelderne takler dette, er interessant å se. Til dels kan vi snakke om unnvikelsesteknikker hos anmelderne som forventes å si noe om meningen i stykket. Ring i Svenska Dagbladet sier: «Det går inte att rakt och entydigt säga vad denna "Edda" vil tala om». Juul i Vårt Land sier noe lignende, og Larsen i Klassekampen sier: «Iblant er det faktisk ganske vanskelig å skjønne hvor Wilson vil». Disse innrømmer altså problemet, men underdriver det kraftig. Bare noen av anmelderne drister seg til å si noe om budskap eller hva vi kan lære av stykket. Svenska Dagbladet avslutter med en tolkning om «miljöansvar och allas framtid». Levin i Aftenposten er inne på noe i 
samme retning: «Mot slutten går alt til helvete for full maskin - krigsmaskiner og antydende roboter forteller hvordan Wilson ser på vår egen tid og vårt eget endelikt».

Anmeldelsene av Edda-forestillingen gir nok ikke norsklæreren det litterært-faglige innholdet som en tradisjonelt forbinder med oppsetninger av klassisk stoff, men til gjengjeld gir de god anledning til analyse innenfor det utvidede tekstbegrepet som denne samtidsteaterproduksjonen representerer, og til å studere hvordan anmelderne angriper tolkingsoppdraget. Dette handler både om sjangerlære og litteraturkunnskap.

Om forholdet mellom stykket og mytologien, blir det sagt lite, naturlig nok, siden det krever spesialkunnskap og anmeldelse som sjanger har sterke begrensninger. Et interessant unntak er Gro Steinsland, som er en av de fremste internasjonale ekspertene på gammelnordisk religion. I en kronikk i Klassekampen (20.03.17) setter hun fingeren på spenningen mellom forventet budskap og uventet nytt perspektiv: «Robert Wilsons teaterstykke er ikke formidlet edda-mytologi som vi kjenner den, men et mytologisk univers der regissøren er gud». Hun poengterer nettopp at den Edda stykket formidler står svært langt fra den egentlige $E d d a$, og at dette først provoserte henne - men at hun etter hvert kom fram til at den tankeprosessen dette utløste kan ha vært Wilsons intensjon. Da har hun satt fingeren på det særtrekket ved kunsten at den både kan skape opplevelse og formidle ny erkjennelse. Enten man har sett denne produksjonen eller ei, er dette en diskusjon det vil være spennende å involvere lærerstudenter i.

\section{Teateranmeldelsene fra et historiedidaktisk perspektiv}

I historiefaget, som utgjør en tredjedel av samfunnsfaget i skolen, har fortellingen fått en dominerende plass i fagets selvforståelse de siste tiårene. Det narrative har blitt et motsvar til kravet om objektivitet og oppfatningen om at historieskriving dreier seg om å skape et bilde av fortiden som på mest korrekt måte representerer fortiden 'slik den egentlig var' (Sandmo, 2013, s. 186-188; Schoubye, 2000, s. 7789). Ved å se på historieskriving som fortelling løfter man fram forfatteren - eller fortelleren - og de valg som er foretatt for å gi fortellingen form og innhold. Historikeren velger ut stoff, velger bort stoff, skjærer til, lager plott, zoomer inn, zoomer ut, lager koblinger mellom fortellinger. Historie forstått på denne måten handler mer om å konstruere enn å rekonstruere, og likner mye på både en litterær vitenskap og teaterproduksjon.

I historiedidaktikken er derfor det narrative ofte koblet til begrepet historiebevissthet. Fortellinger vi skaper og formidler om fortiden gis mening og relevans i nåtiden og påvirker hvordan vi former framtiden, ifølge den tyske historiedidaktikeren Jörn Rüsen (2005, s. 11). Denne måten å tenke om historie på har også preget det norske didaktiske feltet de siste tiårene og med Kunnskapsløftet (Utdanningsdirektoratet, 2013) er begrepet historiebevissthet eksplisitt tatt i bruk i samfunnsfaget $i$ skolen og dermed i lærerutdanningen. Begrepet er nært knyttet til fortellinger som metode. Historie og historisk metode handler blant annet om «hvordan mennesker tenker forskjellig om fortiden, og hvordan dette kommer til uttrykk i fortellinger og i historiske framstillinger» (Utdanningsdirektoratet, 2013, Fellesfaget VG1). En analyse av teateranmeldelser kan brukes for å vise - studenter og andre hvordan historiebevissthet kommer til uttrykk i tekster og hvordan anmeldernes historiebevissthet former deres opplevelse og tolkning av stykket.

Anmeldelsene av Wilsons Edda-oppsetning er interessante i et historiebevissthetsperspektiv der vi ser på det moderne stykkets evne til å aktualisere en tusenårig kulturarv. Steinsland, som har skrevet forordet til DNT-programmet, hevder at Wilson med dette stykket vil «riste oss i teatersalen ut av 
vande spor. For dette er Edda-mytar i gneistrande møte med oss sjølve og vår eiga tid. Vi vil bli overraska, uroa og truleg få ei og anna aha-oppleving i møtet med det tidlause og evig aktuelle i mytologiens biletverd» (Steinsland, 2017). Steinsland hevder at de gamle norrøne mytene har potensial til å aktualisere vår egen samtid, til å stake ut ny kurs, og si noe om fremtiden. Det Steinsland fremholder her som stykkets viktigste funksjon er kjernen i begrepet historiebevissthet. Ved å la studenter analysere hvordan anmelderne av stykket forholder seg til fortiden og prøver å gjøre Eddas univers aktuelt og betydningsfullt, kan de få innsikt i hva historiebevissthet kan være og hvordan det materialiserer seg gjennom språklige uttrykk.

Men klarer Wilsons Edda å aktualisere den norrøne mytologien? Opplever anmelderne et «gneistrande møte med oss sjølve og vår eiga tid»? Og hvordan uttrykker de Wilsons fortellingers potensial til å styrke vår historiebevissthet ved å bygge bro mellom fortid, nåtid og framtid? De åtte anmelderne strever med å finne og forstå de historiske koblingene i forestillingen. De fleste presenterer elementer i teaterstykket som er hentet fra den norrøne mytologien: Fortellingene om Odin i verdenstreet, om Tor som fisker Midgardsormen og om Balders død. Hos Wilson har imidlertid fortellingen en form som ligger veldig fjernt fra den samtidskonteksten som de opprinnelige mytene ble fortalt i. Pettersen (Morgenbladet) karakteriserer oppsetningen som «en visuelt slående forestilling med rom for assosiasjoner som strekker seg i mange retninger.» Denne behandlingen av materialet mener hun framhever mytenes tidløse aspekt. Tematikker som brodermord og tap av barn kan vi kjenne igjen fra annen mytologi, og det er også aktuelt i vår tid. Dette er Levin (Aftenposten) også inne på, i det hun framhever at Wilsons form først og fremst kommenterer vår tid og vårt endelikt. Men de opprinnelige mytene er så utilgjengelige, mener Pettersen, at det er «vanskelig å si om vi er vitne til en tidligere verden som kollapser, eller vår egen».

Kvalvik (Dag og Tid) gir i større grad enn Pettersen uttrykk for at avstanden mellom Wilsons mytiske tablåer og den norrøne gudeverdenen er et problem. Selv om vi kjenner fortellingene om Tor og Odin, har de færreste av oss kontroll på enkelthistoriene i detalj. «Det vert eit problem i ei framsyning som denne, som er visuelt blendande og musikalsk raffinert, men som avstår frå å vere instruktivt forteljande.»

Av dette forstår vi at det visuelle og formtekniske dominerer i så stor grad at det fortrenger budskapet i det mytiske materialet. Kvalvik mener videre at dette hemmer skuespillernes prestasjoner: «Det vert ingen merkbar kontrast mellom dei gode og dei vonde kreftene, heller ingen verkeleg statusskilnad karakterane imellom. Det er kan hende medvite, men dermed vert det heller ikkje så lett å ta inn konfliktane og hendingane som skal drive det heile framover.»

Det som kunne blitt et fruktbart møte mellom den norrøne mytologien og det moderne teaterpublikumet blir et storslått visuelt møte uten substans. «Meir form enn innhald», som Levin utrykker det (Aftenposten). Larsen i Klassekampen er også opptatt av at formen står i veien for at vi klarer å gjøre de norrøne mytene relevante for vår tids verden: «Det er antakelig «den drømmeaktige formen» som gjør at jeg har vanskelig for å oppdage parallellene mellom vår tids myter, og mytene Edda beretter. Til det kreves kanskje både dyptgående kunnskap om «Edda» og en spesiell evne til å knytte Wilsons sceniske elementer til vår moderne tid.»

Juul i Vårt Land er derimot av en annen oppfatning når det gjelder de gamle mytenes gjennomslagskraft i Wilsons tolkning. Hun opplever at de eksistensielle temaene i mytologien blir forsterket nettopp i kraft av at teatret her løsriver det fra sin kjente middelalderkontekst. I stedet for å behandle vår litterære arv med tradisjonstung respekt, lar Wilson mytene bryne seg mot oss selv og vår egen tid og populærkulturelle referanser. Vi tvinges til å justere vår virkelighetsoppfatning, og 
tvinnes inn i en fortelling om jordens tilblivelse og undergang fra et religiøst liv før kristendommens tid. Juul konkluderer med at selv om det står norrøn mytologi på menyen, har den ikke gått ut på dato.

Forsøket på å problematisere hvordan forestillingene om de fortidige norrøne mytene kobles og aktualiseres gjennom Wilsons stykke, eller hvordan Wilson bidrar til å øke bevisstheten om vår historiske arv, viser at det kun er én av anmelderne, Juul, som opplever «å bli ristet ut av vande spor», som Steinsland formulerte det i forordet til programmet. De andre problematiserer avstanden mellom det opprinnelige mytiske materialet og Wilsons iscenesettelse. De framhever at noe har gått tapt på veien, og flere peker på at formspråket står i veien for formidlingen av de norrøne mytenes budskap. Flere av anmelderne peker også på at vi ikke har tilstrekkelig med kunnskap om den norrøne gudeverdenen lenger til å klare å koble referansene som stykket er fullt av. Det gir ingen mening, for vi kjenner ikke mytene godt nok. Larsen gir oss dette bildet: «Når vi kommer inn i salen, troner et reinsdyr midt på scenen - et symbol på Norden?». Det hun oppfatter som reinsdyr, vil nok andre mene er en hjort og assosiere med de fire hjortene som spiste av verdenstreet Yggdrasil. Referansene er mange, men formspråket gjør det svært krevende å tolke dem. Skal fortellinger om fortiden aktualisere og utgjøre en beredskap til å orientere seg i nåtiden, må man altså ha kunnskap om fortiden. Det holder ikke at Wilsons Edda er «festleg å sjå og høyre til» som Kvalvik uttrykker det (Dag og Tid). Det bringer ikke mytene nærmere.

Analysen av de åtte anmeldelsene fra et historiedidaktisk perspektiv viser at anmelderne på ulike måter strever med å forstå Wilsons mytologiske univers. Dermed blir det også vanskelig å se hvordan fortiden kan skape mening i nåtid og fremtid, neo som skaper forvirring og frustrasjon hos de fleste anmelderne, men også glede hos noen. Måten de uttrykker dette på er gode eksempler på hvordan historiebevissthet kommer til uttrykk i tekster. Analyse av teateranmeldelser er derfor et god grep når studenter skal diskutere hvordan et abstrakt begrep som historiebevissthet kan komme til uttrykk, og hvordan det skjer på ulike måter i ulike tekster. Anmeldelsene belyser hver på sin måte bruddflatene mellom fortid, samtid og framtid.

\section{Avsluttende diskusjon}

Hensikten med denne artikkelen har vært å besvare hvordan teateranmeldelser kan brukes som tekster i lærerutdanningene og vise at det finnes andre fagtekster å lese for studenter enn tradisjonell faglitteratur og -didaktikk. Vi har belyst ulike faglige innfallsvinkler og gitt eksempler på hvordan det er mulig å aktualisere og diskutere vår norrøne kulturarv og dens møte med samtidskunst og kultur via teateranmeldelser. I denne prosessen er anmeldelsene tolket både på egne premisser (som anmeldersjanger), i utvidet forstand (som referanse til en scenisk tekstsjanger) og som referanse til den mytologiske sjangeren som $E d d a$-stoffet relaterer seg til. Sjangerforståelse, en utvidet kulturforståelse, samt kritisk lese- og analyseferdighet er kunnskap som forventes av framtidens lærere, men som kan være en utfordrende oppgave i vår tid.

Teateranmeldelser er tekster som alene rommer tankefigurer og språklige bilder som påvirker og former leserens forståelse av tekstene. Vi ser på teateranmeldelsene som en type tekster som virker $\mathrm{i}$ kulturen og i samfunnet der de leses. Med artikkelen er målet vårt at studenter og lærerutdannere sammen utforsker tekstene. De didaktiske eksemplene vi viser er knyttet til teatralisering, religionens rolle, bevegelsesaktiviteter i kroppsøvingsfaget, fagtekster i norsk og historiebevissthet.

Arbeid med teateranmeldelser kan gi nyttige perspektiver på både faglige og didaktiske spørsmål. Eksempelvis vil de kunne skape nysgjerrighet omkring ulike tolkninger av de opprinnelige tekstene. En teateranmeldelse vil også kunne anspore til diskusjon av eksistensielle spørsmål, som her med 
utgangspunkt i $E d d a$-stykket, og på den måten ha en sterk livssynsmessig relevans.

Teateranmeldelsene har et språk, en begrepsbruk og en form som er mulig å benytte i flere lærerutdanningsfag slik vi har gitt eksempler på her.

Selve anmeldersjangeren er interessant fra et undervisningsperspektiv også når det gjelder kritisk refleksjon. Anmeldelser står gjerne i et spenn mellom slakt og anbefaling. Å undersøke anmelderens tekstlige grep, er vesentlig for å finne det underliggende budskapet. Gjennom et slikt arbeid opparbeides en mistenksomhetens hermeneutikk basert på anmelderens (ofte ubevisste) preferanser. Det vil igjen kunne skjerpe studentens evne til å forstå hvordan ens eget ståsted, meninger, politiske preferanser, religion og så videre, er med på å forme de ulike kulturelle debattene i samfunnet, samt øke studentens evne til kritisk lesning og analyse. Den innsikten anmeldelsene gir i (teater)kunstkritikk er viktig i et lærerutdanningsperspektiv. Læreren som kulturarbeider bør være orientert om hva som rører seg i samtidskunsten, og ikke minst om hvordan nye stilarter og sjangrer utvikler seg og bidrar til å transformere «klassisk» stoff til å reflektere samtidsproblematikker. Alle disse perspektivene representerer ferdigheter som understøtter studenters - og elevers - evne til kritisk tenkning og problemløsning. Slik kompetanse er sentral i grunnopplæringen og i lærerutdanningen.

Teateranmeldelser kan anspore lærerutdannere, praksislærere og studenter til å eksperimentere med estetiske undervisningsformer og åpne for kreativ, skapende og variert undervisning. Samtidig handler dette også om å bidra til å gi lærerrollen tilbake noe av en nesten tapt tradisjon, nemlig verdien av læreren som kulturarbeider. Alle lærere kan gjennom å besøke, oppleve og kritisk vurdere kunst- og kulturuttrykk utvide sin egen og sine elevers horisont og bli inspirert til å se kunst- og kultursektoren som supplerende læringsarena egnet til å berike egen undervisning og eget fag.

\section{English Abstract}

The article discusses eight reviews of the theatre production Edda at the Norwegian Theatre in Oslo in 2017. The authors have developed the article collectively, based on our common interest in myths and stories, anchored in the research group «Mythology, folk tale and story-telling in education and pedagogy» at Western Norway University of Applied Sciences (HVL) in Bergen. The authors are researchers and teacher educators in various fields of study. The concrete starting point for the article is Robert Wilson's Edda-production, and its reviews. Our intention is to contribute to enhancing student teachers' cultural competence by exemplifying how theatre reviews can be applied in an educational context. Through a hermeneutic and pedagogical approach based on the different authors' professional vantage points, we discuss how theatre reviews can be utilised as study texts. Although the article relates to a particular production, it can still serve as an exemplary model of how teacher educators can apply theatre reviews in different fields of study - and, perhaps, even inspire to experience theatre.

\section{Referanser}

Avén, G. (red.). (1962). Teaterhistoria. En översikt av teaterns utveckling från äldsta tid til våra dagar. Halmstad: Hallandsposten.

Bennett, R. E. (2009). Why Theatre? A Study of Robert Wilson. Undergraduate Honors Thesis Collection. Paper 35. Butler University. http://digitalcommons.butler.edu/cgi/viewcontent.cgi?article=1036\&context=ugtheses

Bikset, L. (2017, 6. mars). Saganatt i storskala. Dagbladet.

Birkeland, N. R. \& Tønnesen, E.S. (2016). Introduksjon og teoretiske perspektiver. I Elise Seip, T. (2016). Hva gjør loererstudenter når de studerer? (pp. 11-31) Oslo: Scandinavian University Press 
(Universitetsforlaget). https://www.idunn.no/hva-gjor-laererstudenter-nar-de-studerer/1introduksjon-og-teoretiske-perspektiver

Brauneck, M. \& Schneilin, G. (red.). (1986). Theaterlexicon. Begriffe und Epochen, Bühnen und Ensembles, Hamburg: Rowohlt Taschenbuch Verlag.

Brecht, B. (1963). Über experimentelles Theater. I Schriften zum Theater, b. 3. (s. 79-106). Frankfurt am Main: Suhrkamp Verlag.

Christensen, A. M. (2012). Begejstring \& Brutalitet - en guide til anmelderens rolle. København: Informations Forlag.

Clarke, M. \& Crisp, C. (1981). The history of dance. London: Orbis.

Det Norske Teatret. (2017). Edda. Konsept Robert Wilson, Oslo: DNT. http://www.detnorsketeatret.no/framsyningar/edda/

Eberson, B. M.. (2017, 6. mars). Visuell fantasi. VG.

Eliassen, K.H. (2006). Hvilken rolle har dans i den norske skole? Pedagogisk profil, 13(2), 20-25.

Fosse, J. (2017). Edda. Den eldre Edda i ein scenisk versjon ved Jon Fosse. Oslo: Skald.

Fauskanger, J. \& Mosvold, R. (2014). Innholdsanalysens muligheter i utdanningsforskning. Norsk Pedagogisk Tidsskrift, 98 (2), 127-139.

Gunnell, T. (1994). The Play of Skírnir. A new look at the old idea of 'ancient Scandinavian drama'. Nordic Theatre Studies, 7, 21-35.

Gunnell, T. (2008). The Performance of the Poetic Edda. I S. Brink \& N. Price (Red.), The Viking World, (s. 299-303). London: Routledge.

Helgheim, K. (2000). Antonin Artaud. Det dobbelte teater. Oversettelse, kommentarer og etterord. Oslo: Solum forlag.

Hsieh, H-F. \& Shannon, S. E. (2005). Three approaches to qualitative content analysis. Qualitative Health Research, 15, 1277-1288. DOI: https://doi.org/10.1177/1049732305276687

Juul, K. (2017, 6. mars). Teater av en annen verden. Vårt Land.

Kvalvik, B. (2017, 17. mars). Storslege, men ukjenneleg norrønshow. Dag og Tid.

Kværne, P. (2016). Myte. I Store norske leksikon: https://snl.no/myte.

Larsen, I. L. (2017, 6. mars). Gamle myter en ny tid. Klassekampen.

Lehmann, H-T. (2006). Postdramatic Theatre. Translated by Karen Jürs-Munby, London: Routledge. DOI: https://doi.org/10.4324/9780203088104

Levin, M. (2017, 10 mars). Jon Fosses «Edda» er opphav og undergang i evig og malerisk syklus. Morgenbladet.

Lindqvist, A., Erixon, P-O., Segerholm, C. \& Olsson, B. (2010). Dans i skolan: om genus, kropp och uttryck. Ph.D. avhandling. Umeå universitet. Lægreid, S. \& Skorgen, T. (2001). Innledning. I Hermeneutisk lesebok, redigert av Sissel Lægreid \& Torgeir Skorgen. Oslo: Spartacus.

Nordaker, D. J. (2009). Dans i skolen?: En didaktologisk studie av dansens legitimering og innhold $i$ relasjon til den norske grunnskole, sett i lys av nasjonale loereplaner, aktuelle fagtidsskrift og kultur- og utdanningspolitiske dokument. (Doktoravhandling). Århus: Danmarks Pædagogiske Universitetsskole, Aarhus Universitet .

Nyrnes, A. (2002). Det didaktiske rommet. Didaktisk topologi i Ludvig Holbergs Moralske Tanker. (Doktoravhandling). Bergen: Universitetet i Bergen.

Ring, L. (2017, 6. mars). Edda. Nordiska gudasagor på absurt och vackert sett. Svenska Dagbladet.

Rüsen, J. (2005). History - Narration, Interpretation, Orientation. NY og Oxford: Berghahn Books. DOI: https://doi.org/10.2307/j.ctt1 x76fc2

Sandmo, E. (2013). Tid for historie - En bok om historiske spørsmål. Oslo: Universitetsforlaget.

Schoubye, J. (2000). På vej mod historiefortcellingen - refleksioner over faghistorisk kommunikation. København: Danmarks Lærerhøjskole.

Skram, H. F. (2011). Historiefaget i Kunnskapsløftet: Dyktiggjøre og bevisstgjøre. Acta Didactica Norge, 5 (1), 1-29. DOI: https://doi.org/10.5617/adno.1063

Smith, B. H. (2016). What was 'Close Reading'?: A Century of Method in Literary Studies. Minnesota Review, 87 (New Series), 57-75. DOI: https://doi.org/10.1215/00265667-3630844

Steinsland, G. (2005). Norrøn religion. Myter, riter, samfunn. Oslo: Pax.

Steinsland, Gro. (2017). Norrøne mytar som ferskvare. DNT: http://www.detnorsketeatret.no/dybdeartiklar/norrone-mytar-som-ferskvare/

Steinsland, G. (2017, 20. mars). Hva skjedde med Edda? Klassekampen. 
Eriksson. A. S., Hallås. O. B., Heide. E., Brathetland. O. B., Grande. B. P. \& Lyngstad. B. M.:

"Teateranmeldelser som tekster I lærerutdanning"

Thagaard, T. (1998). Systematikk og innlevelse. En innføring i kvalitativ metode. Bergen:

Fagbokforlaget.

Utdanningsdirektoratet (2015). Læreplan i kroppsøving. Nedlastet 15.mars 2018:

https://www.udir.no/k106/KRO1-04/Hele/Formaal

Utdanningsdirektoratet (2013). Læreplan i samfunnsfag. Nedlastet 15.mars 2018:

https://www.udir.no/k106/SAF2-03

Utdanningsdirektoratet (2013). Læreplan i kristendom, religion, livssyn og etikk. Nedlastet 15.mars 2018: https://www.udir.no/k106/RLE1-02

Utdanningsdirektoratet (2013). Læreplan i norsk. Nedlastet 15.mars 2018: https://www.udir.no/k106/NOR1-05

Østbye, G. L. (2007). Barn+ kunst = Danning. Om å fabulere og filosofere i kunstmøter. Oslo: Gurilo forlag. 